\title{
ASSIGNING MADINAH CHARTER ON THE DISCOURSE OF PLURALITY AND TOLERANCE
}

\author{
Seggaf al-Munawwar \\ Sulthan Thaha Saifuddin State Islamic University (UIN) Jambi \\ seggaf.almunawwar1@gmail.com
}

\begin{abstract}
Madinah Charter is one of Nubuwah products that are in harmony with the principle of the Qur'an practices and Islam as the religion of Rahmatan Lil Alamin. This paper discusses the vision of plurality and rejection of intolerance in Indonesia through Madinah Charter as the epicenter of its analysis. The actualization of Madinah Charter in the religious and cultural plurality is still relevant in many majority Muslim countries and is appropriate to prevent intolerant attitudes and ethnic conflicts.
\end{abstract}

Keywords: Madinah Charter, plurality, intolerance

\section{Introduction}

Muslims believe that Islam is the absolute religion than others, but the human differences or diversities are something that Allah has given to us. As we know as plurality. However, the pluralism concept teaches human to the absolute relativity, but not only for ethnicity and culture, but it is also to religion which for Muslims are difficult to accept. The inclusiveness of a Muslim is in the area of muamalah and faith, Muslims are guided by the end of surah Al-Kafirun "For you your religion, for me my religion". However, such the limited inclusiveness has no meaning for intolerance. The teaching of tolerance is also the Qur'anic injunction as the verse "no compulsion in religion".

The drawing of today's intolerance is more targeted to Muslims. As there is a huge wave of information that leads to respect for plurality among Muslims is low. In fact, as described above, tolerance is indeed an Islamic practice. The Prophet himself has displayed the face of tolerance not only in his personal context as the Prophet or uswah to his companions, but also to all different communities of religions and tribes in Madinah. Madinah Charter became a unifying media among communities and a form of tolerance and respectful implementation of plurality that occurred in the seventh century ago. Now, Madinah Charter continues to inspire Muslims in all places of the world. This paper will also elaborate the Madinah charter as a legacy of the Prophet which is still relevant to inspire Muslims, living together with others on earth.

\section{Method}

The research that underlies this paper is the writer's research dissertation that continouesly developed up to now. This paper uses a manuscript in qualitative approach, which examines the texts or contents of Madinah Charter, and conducts of reading works of experts who have first examined the Madinah Charter, then analyzes it with the social situation today, especially on the interpretation of religious teachings which is considered intolerant and interrelated discourse religious and inter- ethnic communities today. 


\section{Result and Discussion Pluralism of Religion}

The word of pluralism etymologically comes from English, so its definition will be relevant referring to its original language. Pluralism means plural or more than one; it has three meanings. First, the ecclesiastical notion: (i) the title for the person holding more than one position in the ecclesiastical structure, (ii) holding two or more positions simultaneously, both of ecclesiastical and non-ecclesiastical. Second, the philosophical notion: means a system of thought that acknowledges the underlying foundation of thought which is more than one. While the third, the socio-political notion: means a system that recognizes the coexistence of diversity of communities, even more for race, ethnicity, party or faith with the fixed term as "religious pluralism" which refers to the theory of the relationship among religions and all their differences and contradictions.

Basically, the recent discourse on "pluralism" that occurred in the Islamic theology environment, has already found outside the Islamic environment, since the early 20th century by theologians of the reformation church and the current of liberation theology. Christian theologians did reform movements, even lawsuits over classical theology. While the Catholic theologian was formulated at the Second Vatican Council of 1964 which originally stated "no salvation outside the church" turned into "salvation everywhere" .7 In the context of Religious Pluralism, is conceptually divided into 3:1) actual pluralism (real plurality) is a belief that diversity is impossible to deny for its existence. 2) the pluralism that connotes politics, so its understanding is often jumbled with the notion of secularism. 3) Pluralism which refers to an understanding on religious theory that religion is basically the way to achieve one destination.

The broad outline of pluralism notion is to acknowledge the existence of diversity and active involvement in pluralism and/or to among believers recognize the existence and rights of other religions, then as the effort in understanding the differences and similarities. However, this is not equal to relativism which states "all religions are the same" and not also syncretism that creates a new religion by combining certain elements of some religions to be integrated (Syihab, 1999 p. 41-42).

Based on classical Islamic idea states that the plurality of religion is delivered textually in the Qur'an, as it is described in QS. Al Baqarah verse 62, Al Maidah verse 69 and Al Hajj verse 17 (Nurwahid, 2004, p. 41-63). The reality of religion plurality affirms three basic principles: (1) Islam brought by the prophet Muhammad S.A.W is a continuation and justification as well as the closing of series previous celestial religions such as Ibrahim, Moses, Isa-before the religions were renamed and falsified-by their followers. He even calls on the scribes to go to the phrase "sawa" (true) and also "furqan" (Surah Ali Imran: 64). (2) Strictly proclaims that Islam is brought by the Prophet Muhammad S.A.W as the only one religion approved by Allah (Surah Ali Imran: 19 and 85). (3) Recognizing the freedom of religion choice and there is no compulsion for religion choice (Surah Al Baqarah: 256 and Al Mumtahanah: 8).

The scholars of classical commentary give explanations on plurality phenomenon which does not lead to an understanding of pluralism. This phenomenon has emerged since the period of Mekah as the expression of rejection to Quraysh mushrikeen against the concept of tauhid which is considered strange (Surah Shad: 5). Such a pluralism idea arises in the occurrence of the decree of surah al-Kafirun's on the offer of some Quraysh elders to the prophet Muhammad to jointly worship the God "you worship our God and we worship your God".

Therefore, even if the classical Islamic thinkers refuse the religion practice of 
others than Islam and do not recognize the concept of religious pluralism and/or the principle of pluralism, but they accept the existence of religious pluralism and diversity of religious practices, thus it is also concerned with religious tolerance, living in harmony, mutual respect and building together civilization and social life. As it is ion the jargon of "No Pluralism, Tolerance Yes" it underlines the respect of among other mankinds (Surah al-Isra: 70), the obligation is to remind others and but not to impose belief (QS Al Ghasyiyah: 21-23), the existence of religious differences is Allah's will to give freedom for all mankinds to choose their own belief (Surah Al Kahfi: 28 and Yunus 89), the command to do equity to anyone including to non- Muslims, even so to be noble for mushrikeen is written in the Qur'an (Surah al- Maidah: 8), as well as guarantees of protection from Rasulullah to Ahlu Dzimmah.

\section{The Religious Principles in Madinah Charter}

The spirit of Madinah Charter is completely in line with the Prophet Muhammad (S.A.W) explanation that all religions messaged to prophets are basically same. This principle is also explained in the Qur'an that Allah creates the same religion for all prophets, like the prophets Nuh and Muhammad as prescribed to the Ibrahim, Musa and Isa. All ummah must uphold the same religious law and are not allowed to divide within it, since the ummah of the Prophets uphold the one and same Allah. (Nurcholish Madjid, 2004, p. 49-50.) This Madinah Charter's point of view is an affirmation of the pluralism which is naturally based on Allah's will that mankind are diverse, so it must be accepted principally and consistently. In this context, the are 5 (five) principles in Madinah Charter: 1) Belief in the One Supreme (Monotheism). 2) Religious Freedom 3) Internal Relations and Interfaith Society. 4). Religious Tolerance. 5) Neighbors and Mutual help.

\section{Belief in the One Supreme (Monotheism)}

This principle is found specifically in Rabbaniyah (divine) "all of siasah activities refer to the derived law or values from Allah or the model of Prophet Muhammad." 11 In this Divinity, Madinah Charter of this principle is contained in Mukaddimah and articles 22, 23, 42 and 47 which essentially calls for the recognition of the existence of Allah in life, therefore in the settlement of all mankind cases; the reference must to be Allah.

\section{Religious Freedom}

This principle is in accordance with the statement of the Qur'an in QS Al Baqarah verse 256 (Nurwahid, 2004, p. 41-63) as the basis to mention the guarantee of religious freedom and the absence of compulsion in choosing a religion. In Madinah society, the freedom is not only at the level of ideas, but it is manifestly realized for all regardless to ethnic, racial, ethnic, social and religious differences. It is developed and guaranteed for its implementation in order to create a pluralistic society. Such freedoms include; religious freedom (articles 25-35), freedom of customs and values (articles 2-10), freedom of deficiency (article 12), freedom of persecution (articles 1636), freedom of fear (article 47) and freedom of expression (articles 23 and 37). (Ismail, 1998, p. 49-50).

In Madinah Charter, this principle is understood from the clause which states that both of Jews with its various tribes and Muslims still adhere to their respective religions (article 25-35). This means that religious freedom is constitutionally guaranteed by nation, so the Prophet Muhammad S.A.W in his capacity as a Prophet and the head of nation did not force those who were not yet Muslims to accept Islam. They were given the freedom to do their customs and values such as taking and paying (diat) to the prisoners (article 2-10). It is in accordance to the Qur'an which 
stipulates if the law of qisas is not executed because the slain family forgives the killer family, then the alternative is the killer must pay diat to the slain family in a propper way (QS 2. Al Baqarah: 178).

\section{Internal Relations and Interfaith Society.}

In the courage of holding the principles and beliefs of Islam, Rasulullah S.A.W build civilization and social relationships that are proactive and appreciative with adherent of other religions. Madinah Charter was arranged in a pattern of relations between the people of Madinah who are Muslims to Jewish and Arab mushrikeen, as well as internal relationship among them. The internal relationship of these religious people (Islam, since the Prophet Muhammad himself is a Muslim) was carried out earlier. The measures included setting up the Quba Masjid. This masjid is built as a place to worship and a meeting of Muslims, as well as Nabawi masjid in Madinah which has inspired its role and function to all masjids. These masjids are recorded has 10 (ten) roles in history, there are: 1). Place of worship (prayer and zikr), 2). Place for communication and consultation (economic, social and cultural issues), 3). Place of education, 4). Place of social compensation, 5). Military training ground and the preparation of its equipment, 6). Place for treatment of war victims, 7). Place of justice and dispute court, 8). Hall and reception area, 9). Place as a jail 10). The center for illumination or religion defense. So the masjid's functions in the time of Prophet Muhammad are not only stopped as a place to carry out activities of worship alone, but broadly as the center of all activities for the interaction of ummah. The Quba masjid was also part of the efforts to unite the Muhajirin and Ansor which provided a strategic meaning to mobilize the unity of ummah. The steps taken by the Prophet have the legitimacy of revelation (Surah 8: 72), meaning "Those who believe and hijra (the muhajirin) and strive with their resource and souls in the way of Allah, and the people (the Ansar) who give a place to stay and assistances, they protect each other".

On the other hand, the Qur'an also affirms that human beings establish a harmonious social relationship between muslims and other religions as long as Muslims are not fought and not tyrannized (Surah al-Mumtahanah: 8). In Madinah Charter this principle is contained in a case of defense and security which aims to establish interreligious relations of interfaith society (Madjid, 1997, p. 34.) in article 24, 37, 38, and 44, generally to all Madinah. These chapters read: "Verily the Jews and the believers work together to bear the finances during their warfare" (chapter 24), "The Jews are obliged to bear with their livelihood and muslims should bear with their own livelihood. But between them there shall be cooperations or assistances facing to those who attack the people of sahifah, they mutually give input and together create positive environment, not committing sin" (article 37)," Jews and Muslims (article 38 ), and "Surely among them there shall be co-operation, helping each other against those who attacked the city of Yasrib" (article. 44)

\section{Religious Tolerance}

The next aspect of religious freedom relates to the issue of tolerance. However, the issue is how we can allow for others to have their own religion practices, if we do not understand the word tolerance, both to people and intra-religious communities. Tolerance can be interpreted as tolerant or understanding (appreciating, letting, allowing) resolute (opinions, views, beliefs, habits, behavior, etc.) that are different or contrary to their own stance. Mukti Ali refers to "Agree in disagreement" (being agree in disagreement or agree in difference). Tolerance can also mean endurance or fortitude, which not only shows the attitude of letting others live around us without restrictions and persecution. Tolerance in this sense, especially in the field of religion, refers to the willingness and agreement to enter and impose other religions respectfully 
in a dialogue with others constantly without being influenced by other opinions in the dialogue. This principle is implied in the Madinah Charter in article $25-35$.

\section{Mutual assistance among Neighbors}

In Madinah Charter, this principle is part of the socio-cultural and economic life starting from the smallest community that is neighborhood. The adjacent matters as stipulated in article 40 of Medinah Charter, said: "Surely the neighbor is like who we are, we should not treat them bad", should not hurt their heart. Therefore, the Prophet once said which means: "Who believes in Allah and the judgment day, then let him not hurt his neighbor." (Dawud, 1952, pg. 341) In Madinah Charter, this principle means for everyone to shall not harmful each other but to treat others as they do for them self, and ease other's burdens and mutual assistances as mentioned in article 37 "Surely Jews are obliged to bear with their own livelihood and Muslims are obliged to bear with their own livelihood. But among them there should be cooperation or mutual assistance ..."

The Matrix of Plurality and Tolerance Principle originate from Medinah Charter and the Qur'an

\begin{tabular}{|l|l|l|l|}
\hline No & Principle & Madinah Charter & The Qur'an \\
\hline 1 & Believe to the Supreme God & Article 22, 23,42 and 47 & Al-Ikhlas 1-5 \\
\hline 2 & Religious Freedom & $\begin{array}{l}\text { Religious Freedom (article } \\
25-35) \\
\text { Freedom of customs and } \\
\text { values practices (article 2- } \\
10 \text { ) } \\
\text { Freedom of deficiency } \\
\text { (article 12) Freedom of } \\
\text { tyrannized (article 16-36) } \\
\text { Freedom of fear (article 47) } \\
\text { and Freedom of expression } \\
\text { (article 23 and 37). }\end{array}$ & \\
\hline 3 & $\begin{array}{l}\text { Internal Relations and } \\
\text { interfaith Society }\end{array}$ & Article 25-35 verse 256 & \\
\hline 4 & $\begin{array}{l}\text { Religious Tolerance } \\
\text { Article 24, 37, 38, and 44, }\end{array}$ & A1 Mumtahanah: 8 \\
\hline 5 & $\begin{array}{l}\text { Neighbors and mutual } \\
\text { assistance }\end{array}$ & Article 37, Article 40 & A1 Mumtahanah: 8 \\
\hline
\end{tabular}

\section{Contextualization of Madinah Charter}

Countries with a Muslim majority are essential to refer Madinah Charter. Indonesia is as a Muslim majority but a multicultural country with about 250 ethnic groups with more than 250 subcultures and local languages. There are 5 or 6 official religions with different ethnic backgrounds and schools. In the are of religion, first came religion was Hinduism, followed by Buddhism, Islam, then Christianity (Protestant and Catholic), and also the arrival of Chinese who brought the practice of Confucianism. The presence of these great religions especially Hinduism, Buddhism and Islam in addition to the religious values, it also contains political value. As it is seen in the form of Hindu, Buddhist and Islamic kingdoms. Meanwhile the arrival of 
Western invaders coincided with Christian missionaries. (Effendi, 1985, p. 169-170).

In international context, Madinah charter includes bridging inter-religious relations in several Muslim minority countries such as Thailand, the Philippines and Myanmar where the Muslim community feels alienated. The Muslim community can refer to Madinah Charter as a source of shari'ah because it is the sunnah of the Prophet to produce points that can be negotiated with the circumstances in each place. In the present days, all countries are urged to adopt a democratic political approach, because the state as the highest institution is entitled and obliged to pay attention to the plurality of religion and beliefs of their people.

Democratization becomes a space to maintain harmony among religious people. The country's attention to plurality of religion must be democratic. The politics of religious pluralism is a political recognition of competing claims to the sources and powers of the state and the validity of all religious ideologies. Religious pluralism can not be understood as a political arrangement that setlled after the major religions have been given official status, while minorities are marginalized. But the most important thing is to take care of social value to maintain plurality by upholding democracy as it should be.

\section{Conclusion}

Madinah Charter that has been postulated during the life of Prophet Muhammad S.A.W in 14 centuries ago, and still relevant for today. Madinah Charter can generate to five principles that can take care of religious and cultural diversity in Muslim majority countries.

\section{References}

Coward, H. (1989). Pluralisme tantangan bagi agama-agama. Yogyakarta: Kanisius.

Dawud, A. (1952). Sunan Abu Dawud. Cairo: Maktabah Mustafa al-Bab al-Halabi.

Dean, T. 1995). Religious pluralism and truth. New York: State Univesity of New York Press.

Effendi, D. (1985). Dialog antar agama: bisakah melahirkan teologi kerukunan? in Agama dan Tantangan Zaman: Pilihan Artikel Prisma 1975-1984. Jakarta: LP3ES.

Ismail, N.M. (1998). Jatidiri Partai Keadilan. dalam Sahar L. Hasan (editor, dkk), Memilih Partai Islam. Jakarta: Gema Insani Press.

Madjid, N. (2004). Indonesia Kita. Jakarta: Paramadina.

Madjid, N. (1997). Kaki langit peradaban Islam. Jakarta: Paramadina.

Nurwahid, H. (2004). Mengelola masa transisi menuju masyarakat madani. Jakarta: Fikri Pub.

Shihab, M.Q. (1996). Wawasan Alquran, tafsir maudu`i atas berbagai persoalan umat. Bandung: Mizan.

Syihab, A. (1999). Islam inklusif: menuju sikap terbuka dalam beragama. Bandung: Mizan.

Thoha, A.M. (2006). Tren pluralisme agama: tinjauan kritis. Jakarta: Perspektif.

Tanja, V.L (1998). Pluralisme agama dan problema sosial. Jakarta: Cidesindo. 